\title{
Reverse Transcriptase Sequencing of 16S Ribosomal RNA from Faenia rectivirgula, Pseudonocardia thermophila and Saccharopolyspora hirsuta, Three Wall Type IV Actinomycetes Which Lack Mycolic Acids
}

\author{
By T. MARTIN EMBLEY, ${ }^{1}$ JAN SMIDA ${ }^{2}$ AND ERKO STACKEBRANDT ${ }^{2 *}$ \\ ${ }^{1}$ Department of Paramedical Sciences, North East London Polytechnic, London E15 4LZ, UK \\ ${ }^{2}$ Institut für Allgemeine Mikrobiologie, Christian-Albrechts-Universität, $2300 \mathrm{Kiel}, \mathrm{FRG}$
}

(Received 25 September 1987; revised 10 December 1987)

\begin{abstract}
The phylogenetic relationships of three mycolateless wall type IV actinomycetes, Faenia rectivirgula, Pseudonocardia thermophila and Saccharopolyspora hirsuta, were examined using reverse transcriptase sequencing of $16 \mathrm{~S}$ ribosomal RNA. The sequences generated were aligned and the level of sequence homology calculated. The homology values were then used to produce a phylogenetic tree and to estimate $S_{\mathrm{AB}}$ values for the construction of a dendrogram. Both analyses show the three taxa to be closely related genera which form a distinct subdivision within the broader phylogenetic grouping defined by Mycobacterium, Dactylosporangium and their relatives.
\end{abstract}

\section{INTRODUCTION}

Actinomycetes which contain meso-diaminopimelic acid, arabinose and galactose in their cell envelope (wall type IV sensu Lechevalier \& Lechevalier, 1970) can be divided into at least two groups based on the presence or absence of mycolic acids. Representatives of Corynebacterium, Mycobacterium, Nocardia and Rhodococcus all contain these compounds while the genera Actinopolyspora, Amycolata, Amycolatopsis, Faenia, Pseudonocardia, Saccharopolyspora and Saccharomonospora do not (Goodfellow \& Cross, 1984). The latter mycolateless genera are morphologically and phenotypically diverse but can also be subdivided to some extent using chemotaxonomic characters (Lechevalier et al., 1977, 1986; Kroppenstedt, 1985; Embley et al., 1986, 1988).

Ribosomal RNA analyses are currently the most powerful methods available for determining phylogenetic relationships (Stackebrandt \& Woese, 1981; Woese, 1987). rRNA cataloguing has been used to analyse the higher relationships among many actinomycetes and the distribution of chemotaxonomic markers has been shown to correlate with phylogeny to a high extent (Stackebrandt \& Schleifer, 1984). The mycolateless wall type IV actinomycetes have not been included in cataloguing studies (Stackebrandt, 1986). Sequencing of 16S rRNA using reverse transcriptase (Qu et al., 1983) and 'universal' primers (Lane et al., 1985) has recently been introduced as an improved alternative to cataloguing. Using reverse transcriptase, approximately $75 \%$ of the $16 \mathrm{~S}$ rRNA sequence can be determined routinely (Lane et al., 1985), which compares favourably with the $40 \%$ obtained using the cataloguing procedure (Stackebrandt \& Woese, 1981). This larger amount of sequence can also be analysed (Hori, 1975) to provide information on the relative speeds of RNA clocks for different organisms.

In the present study, 16S rRNA from three mycolateless wall type IV actinomycete strains was sequenced using the reverse transcriptase method. Since Faenia rectivirgula, Pseudonocardia thermophila and Saccharopolyspora hirsuta share many chemotaxonomic features (Lechevalier $e t$ al., 1977; Kroppenstedt, 1985; Embley et al., 1988) the possibility that they might form a distinct phylogenetic subgroup within the actinomycetes was therefore investigated. 


\section{METHODS}

Strains and cultivation. The type strains of Faenia rectivirgula (ATCC 33515), Pseudonocardia thermophila (ATCC 19285) and Saccharopolyspora hirsuta (ATCC 27875) were grown to approximately early stationary phase in shake-flasks of nutrient broth (Difco) at $45^{\circ} \mathrm{C}$. Cells were harvested by centrifugation, washed with cold $\left(4^{\circ} \mathrm{C}\right)$ Tris/EDTA buffer $(10 \mathrm{~mm}$-Tris/ $\mathrm{HCl}, 1 \mathrm{~mm}$-EDTA, $\mathrm{pH} 7 \cdot 2)$ and stored at $-70^{\circ} \mathrm{C}$.

Extraction of cellular RNA. The method used was modified from that described by Johnson (1981). Approximately $5 \mathrm{~g}$ wet weight of cells was resuspended in $10 \mathrm{ml}$ cold $\left(4^{\circ} \mathrm{C}\right)$ standard saline citrate (SSC, comprising $0.15 \mathrm{M}-\mathrm{NaCl}, 0.015 \mathrm{M}$-sodium citrate, $\mathrm{pH} 7.0)$ and lysed by shaking with $45 \mathrm{~g}$ glass beads $(0 \cdot 10-$ $0.11 \mathrm{~mm}$, Braun) for $35 \mathrm{~s}$ in a cell homogenizer (Braun). The supernatant was extracted twice with SSC-saturated phenol, and total nucleic acids were precipitated with 2 vols absolute ethanol at $-20^{\circ} \mathrm{C}$. The nucleic acid pellet was homogenized in 10 pellet volumes of cold $\left(4^{\circ} \mathrm{C}\right) 6 \mathrm{M}$-sodium acetate at pH 6.0 (Kirby, 1968) using an Ultra Turrax (Janke \& Kunkel, Breisgau, FRG). The RNA was sedimented by centrifugation at $10000 \mathrm{~g}$ and the sodium acetate treatment repeated until the pellet was clear or only slightly turbid. The sodium acetate was decanted, the pellet redissolved in sterile distilled water and the RNA precipitated with ethanol at $-20^{\circ} \mathrm{C}$. The precipitated RNA was then redissolved in sterile distilled water, the yield determined spectrophotometrically at $260 \mathrm{~nm}$, and the solution diluted to give a final concentration of $3 \mu \mathrm{g} \mu \mathrm{I}^{-1}$.

Reverse transcriptase sequencing of RNA. The method devised by Lane et al. (1985) was used to sequence $16 \mathrm{~S}$ rRNA from the test strains. The nine primers used in the sequencing reactions included (in IUB nomenclature with Escherichia coli 3 ' position indicated): 1, CTGCTGCCTCCCGTA (357); 2, GTATTACCGCGGCTGCTG (536); 3, TCTACGCATTTCACCGCTAC (704); 4, CTACCAGGGTATCTAAT (803); 5, CCGTCAATTCATTTGAGTTT (926); 6, AGGGTTGCGCTCGTTG (1115); 7, CATTGTAGCACGTGTGTA (1241); 8, CGGTGTGTACAAGGCCC (1401); 9, GGTTACCTTGTTACGACTT (1510). Primer sequences 1,3 and 6 were originally devised by C. R. Woese (personal communication), 9 and 2 by Lane et al. (1985), 5 and 4 by G. E. Fox (personal communication), and 7 by J.S. and E.S. All of the primers used in the present investigation were synthesized by standard methods using an Applied Biosystems 3801A DNA synthesizer. In some sequencing reactions, masking bands were a problem and in order to resolve these ambiguities, terminal transferase was used to elongate prematurely terminated fragments (de Borde et al., 1986). The products of all the sequencing reactions were separated using $55 \mathrm{~cm}$ wedge-shaped $(0.2-0.6 \mathrm{~mm}) 6 \%(\mathrm{w} / \mathrm{v})$ polyacrylamide denaturing $(7 \mathrm{M}$-urea) gels (Chen \& Seeburg, 1985). Two gels were routinely run for each reaction: a short run in which the bromophenol blue tracking dye was allowed to migrate $55 \mathrm{~cm}$ and a long run in which the xylene cyanol dye was allowed to migrate the same distance. All separations were performed using an LKB Macrophor 2010 sequencing apparatus operated at $50 \mathrm{~W}$ per gel.

Data analysis. The sequence data generated using the nine primers were aligned and homology values computed with the aid of the Beckman Microgenie program (Queen \& Korn, 1984). Positions where a nucleotide could not be determined unambiguously (designated $\mathrm{n}$ ) in two or three sequences were not included in these calculations. An ambiguous base in only one of the sequences reduced the length of comparable sequence for that strain by one base. Where homologous deletions occurred in two sequences, they were treated as a positive match. $K_{\text {nuc }}$ values (nucleotide substitution rate or 'evolutionary distance values'; Hori, 1975) were calculated and a phylogenetic tree produced using the algorithm of Fitch \& Margoliash (1967) contained in a program written by Felsenstein (1982) (PHYLIP version 2) for the IBM PC.

\section{RESULTS AND DISCUSSION}

The sequencing strategy used in the present investigation generated between 1263 and 1305 bases of 16S RNA sequence for Faenia rectivirgula, Pseudonocardia thermophila and Saccharopolyspora hirsuta, of which 1122 bases could be unambiguously aligned (Fig. 1). Table 1 shows the homology values calculated for these regions in the test strains and selected reference organisms (J.S. \& E.S., unpublished results). $K_{\text {nuc }}$ values are also shown in Table 1 ; these were used to construct a phylogenetic tree (Fig. 2). Pseudonocardia thermophila, Saccharopolyspora hirsuta and Faenia rectivirgula (for convenience hereafter referred to as the PSF group) are more closely related to each other than to the reference organisms (Fig. 2). The taxonomic rank of this relationship appears to be at the level of closely related genera as judged by the branching pattern of reference genera (Fig. 2). The phylogenetic coherence of the PSF group confirms the findings of previous taxonomic investigations which suggested that Pseudonocardia thermophila, Saccharopolyspora hirsuta and Faenia rectivirgula form a distinct centre of variation within the actinomycetes (Embley et al., 1986, 1988). Thus, all three contain phosphatidylcholine (Lechevalier et al., 1977; Kroppenstedt, 1985) and an unusual dimethyl-branched fatty acid 
Fr nGUGGGGUUUUGAAAGUUCCGGCGGUAUGGGAUn. GCUUGCGGCCUAUCAGCURZUUGGUGGGGUnAUGGCCUACCAAGGCGACGACGGGURGCCGGCCU Sh CUUUGUUUGUGGAAAGUUCUGGCGGUCCAGGAURAGCCnRCGGCCUAUCRGCURGUURGUGGGGUGAUGGCCUACCAAGGCGACGACGGGUAGCCGGCCU PT GUUCUGGUGUGGAAAGUUUUUCGGCUGGGGAUG. GCCCGCGGCCUAUCAGCUNGUUGGUGGGGUAUGGCCUACCAAGGCGAUGGAGGGUAGCCGGCCU

Fr nAGAGGGUACCGGCnACACUGGGACUGAGACACGCCCUAGACUCCUACGGGAGRUAGCAGUGGGRAAUCUnGCGCAAUGGGUGAAAGCCUnAUGCAGCA Sh GAGAGGGUIACCGGCCACACUGGGACUGAGACACGGCCURGACUCCUACGGGAGGCAGCAGUGGGGAAUCUUGCGCAAUGGGCGAAAGCCURACGCAGCA PT GAGAGGGUGACCGGCGACACUGGGACUGAGACACGGCCUAGACUCCUACGGGAGGCAGCAGUGGGGAUAUUGCGCAAUGGGCGARAGCCUNACGCAGCG

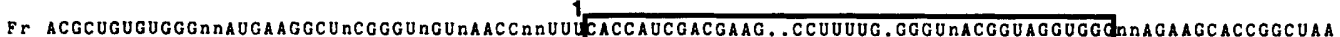
Sh ACGCCGCGUGGGGGAUGACGGCUUCGgGUUGURAACCUnUUU CGACAUCGACGAAGCCAUCUUUGGUGGUGACGGUAGGUGU GAAGAAGCACCGGCUAR

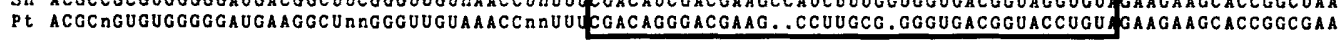

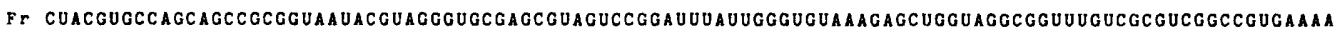
Sh CUACGUGCCAGCAGCCGCGGUAAUACGUAGGGUGCGAGCGUUGUCCGGAUUUAUUGGGCGUAAAGAGCUCGUAGGCGGUUUGUCGCGUCUAUCGUGAAAA Pt CUACGUGCCAGCAGCCGCGGUAAUACGUAGGGUGCGGCGUUGUCCGGAAUUAUUGGGCGUAAAGGCUCGUAGGCGGUGUGUCGCGUGGCOGUGAAAA

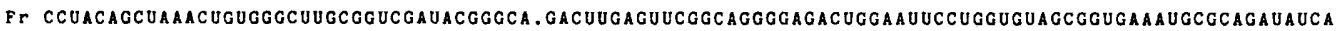
Sh CCGGGAGCUNAACUCCUNGCUUGCGGUGGAUACGGGCA. GACUUGAGUUCGGCAGGGGAGACUGGAAUUCCUGGUGUAGCGGUGAAAUGCGCAGAUAUCA Pt CUUUCAGCUUAACUGGGAGCUUGCGCUCGAUACGGGCAUCACUAGAGUUCGGCAGGGGAGACUGGAAUUCAAGGUGAGCGGUGAAUGCGCAGAUAUCU

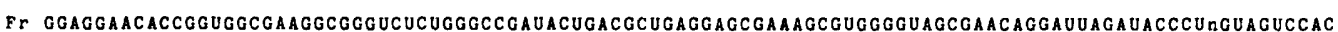
Sh GGAGGAAC RCCGGUGGCGAAGGCGGGUCUCUUGGCCGAUACUGACGCUGAGGAGCGAAAGCGUGGGR. AGCGAACAGGAUUAGAUACCCURGUAGUCCAC PT UGAGGAACDCCGGUGGCGAAGGCGGGUCUCURGGCCGAUACUGACGCUGAGGAGCGAAAGCGUGGGG. AGCGAACAGGAUUAGAUACCCURGUAGUCCAC

Fr GCCGUAAACGGUGGGCGCUAGGUGUGGGRACUnGUUCCACGGUUUCCGUGCCUUAGCURACGCAUUAAGCGCCCCGCCURGGGAGUACGGCCGCAAGGCU Sh GCCGUAAACGUUGGGCGCUAGGUGUGGGGAUGGGUUCCACUGUUUCCGUGCCUUAGCURACGCAUUAAGCGCCUCGCCURGGGAGUACGGCCGCAAGGCU Pt GCCGUAAA CGGUNGGCGCUNGGUGUGGGGGCUA. UUCCACGGUCUCUGUGCCGCAGCUAACGCAUUAAGCGCCCCGCCUGGGGAGUACGGCCGCAAGGCU

Fr AAAACUCAAAGGAAUUGACGGGGRCCnGCACAAGCGGCGGAGCAUGUGGAUUAAUUCGAUGRACGCGAAGAACCUUACCUGGGUUUGACAU CACUnGa Sh AAAACUCAAAGGAAUUGACGGGGRCCIGCACAAGCGGCGGAGCAUGUGGAUUAAUUCGAUGRAACGCGAAGAACCUUACCUGGGUUUGACAUOCACUAGA PT AAAACUCAAAGGAAUUGACGGGG ICCRGCACAAGCGGCGGAGCAUGUGGAUUAAUUCGAUGRARCGCGAAGAACCUUACCUGGGUUUGACAUCCACCGGA

Fr UCGCCCUAGAGAUACG CGRCCCUnGUnGCURGUGCACAGGURGUGCAUnGCURUCGURAGCURGUGUCGUGAGAUGUUGGGUAAAG

Sh CAGCCCCUGAGAGGGG nGnCCCUnGUnGUUGGUGUACAGGUnGUGCAUnGCUGUCGUCAGCUCGUGUCGUGAGAUGUUGGGURAAC

Pt CGCGUCUAGAGAUAGGOGIICCCUUGUnGCCGGUNUGCAGGURGUGCAUGGCUGUCGUCAGCUCGUGUCGUGAGAUGUUGGGURAAGACCCGCAAUGAGC

F r

Sh

Fr CCCCUUAUGCCUAGGGCUUCACACAUGCUACAAUGGCCGGUACAGAGGGUGGCGAGACCGUGAGGUGGAGCGAAUCCCAGAAAGCCGGGRUCAGUUCGGA

Sh CCCCUUAUGCCUAGGGCUUCACACAUGCUACAAUGGCCGGUACAGAGGGCUGCGAGAUCGUGAGGUUGAGCGAAUCCCUnAAAGCCGGRIURAGUUCGGA

Pt CCCCUUAUGCCUAGGGCUUCACACAUGCUACAAUGGCCAGUACRGAGGGCUGCGAGACCGUGAGGUGGAGCGAAUCCCURAAAGCURGRIUCAGUUCGG

Fr UCGGGGUCUGCACCUAGCCCIRGUGAAGUCGGAGUCGCUAGUAAUCGCAGAUCAGCAAUGCUGCGGUGAAUACGUUCCCGGGCCUUGUACACACCGC RCG Sh UCGGGGUCUGCACCURGCCCCCGUGAAGUCGGAGUCGCUAGUAAUCGCAGAUCAGCAUUGCUGCGGU

Pt UCGGGGUCUGCARCURGCCCCCGUGAAGUUGGAGUCGCUAGUAAUCGCAGAUCAGCAUUGCUGCGGU

Fr UCACGUCAUGAAAGUCGGUAACACCCGAACCCAUGGCCCAACCCCGUGUGGGGGa. GGGAGURGUCGAAGGUGGGACURGCGAUC

Sh GUCAUGAAAGACGGUAACACCCGAACCCAUGCCCCAACC. CUUGUGGG... . GGGAGURGUCGAAGGUGGGACURGCGAUC

Pt GUCAUCAAAGUUGGUAACACCCGAACCGAUGCCCUAACCUCUUCGGGGG̈. GGGGAGUCGUCGAAGGGGGACCGGCGAUC

Fig. 1. Alignment of 16S rRNA partial sequences from Faenia rectivirgula (Fr), Saccharopolyspora hirsuta $(\mathrm{Sh})$ and Pseudonocardia thermophila $(\mathrm{Pt})$. The first nucleotide in the $S$. hirsuta sequence and the last nucleotide in the sequences of all three strains are analogous to positions 98 and 1485 (IUB numbering) of the $E$. coli $16 \mathrm{~S}$ rRNA sequence (Brosius et al., 1978), respectively. Boxed sequences indicate highly variable regions that may serve as suitable target sites for oligonucleotide probes. The $5^{\prime}$ nucleotides of the regions are analogous to positions 440 (box 1) and 997 (box 2) of the E. coli sequence.

(Embley et al., 1987, 1988), and they form a tight cluster when their fatty acid composition is compared by principal components analysis (Embley et al., 1988). Differences in menaquinone composition (Collins et al., 1977; Kroppenstedt, 1985; Embley et al., 1986), morphology (Dorokhova et al., 1969; Henssen \& Schäfer, 1971; Lacey \& Goodfellow, 1975) and many phenotypic features (Lacey \& Goodfellow, 1975; Goodfellow \& Pirouz, 1982) support their classification as distinct genera. The separation of the PSF group from wall type IV taxa which contain mycolic acids and from Dactylosporangium aurantiacum is also strongly supported by available chemotaxonomic data (Minnikin \& Goodfellow, 1981; Collins et al., 1982; Kroppenstedt, 1985). Clustering of the wall-type IV actinomycete Amycolata autotrophica with Dactylosprangium aurantiacum, which has a wall chemotype II (Fig. 2) may be clarified as more actinomycete rRNA sequences become available for comparison. Amycolata autotrophica shares a number of chemotaxonomic characters with Pseudonocardia thermophila and relatives but can be distinguished by its fatty acid composition and polar lipid profile (Lechevalier et al., 1986; T.M.E., unpublished data).

The limited number of complete or nearly complete 16S RNA sequences determined in actinomycetes makes it impossible to directly ascertain the position of the PSF group relative to 


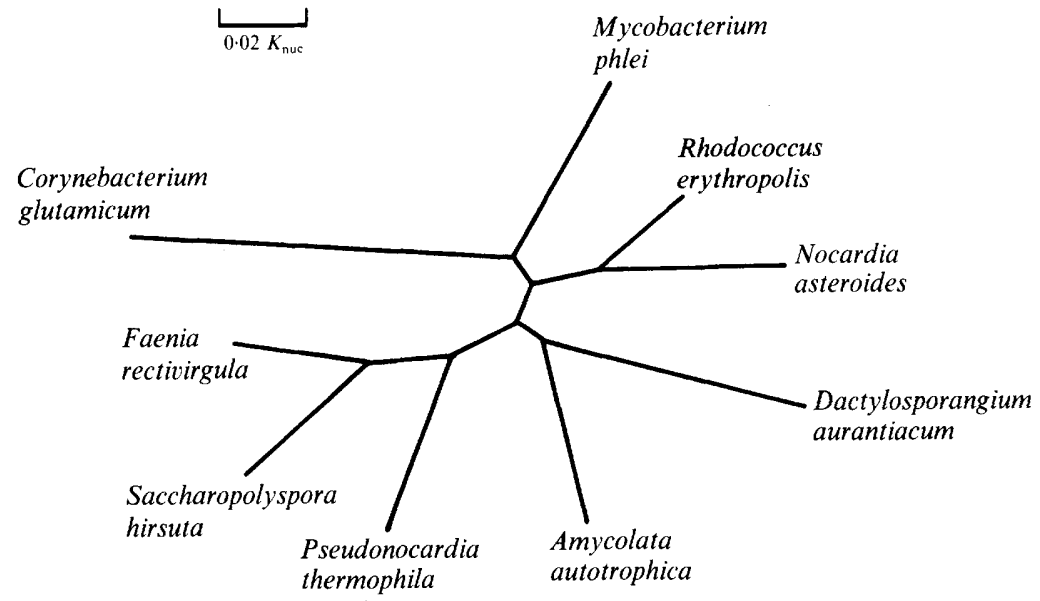

Fig. 2. Unrooted phylogenetic tree showing the relationships between the test and reference strains, based upon $K_{\text {nuc }}$ values contained in Table 1, lower left section.

Table 1. Comparison of phylogenetic parameters derived from $16 S \mathrm{rRNA}$ partial sequences and $16 S \mathrm{rRNA}$ catalogues of test and reference strains

The lower left section shows (upper rows) homology values based on the alignment of 1122 nucleotides and (lower rows) $K_{\text {nuc }}$ values derived therefrom; the upper right section shows (upper rows) $S_{\mathrm{AB}}$ values, calculated from complete $16 \mathrm{~S}$ rRNA catalogues and (lower rows) derived $S_{\mathrm{AB}}$ values (see text). The sequences of organisms 4-9 are derived from unpublished data of J.S. and E.S. The B. subtilis sequence was published by Green et al. (1985). ND, Not determined.

1. Faenia rectivirgula ATCC 33515

2. Saccharopolyspora hirsuta ATCC 27875

3. Pseudonocardia thermophila ATCC 19285

4. Amycolata autotrophica DSM 535

5. Dactylosporangium aurantiacum DSM 43157

6. Mycobacterium phlei TMC 1516

7. Nocardia asteroides DSM 43005

8. Rhodococcus erythropolis DSM 43188

9. Corynebacterium glutamicum DSM 20300

10. Bacillus subtilis

\begin{tabular}{|c|c|c|c|c|c|c|c|c|c|}
\hline 1 & 2 & 3 & 4 & 5 & 6 & 7 & 8 & 9 & 10 \\
\hline & & & & & & & & & \\
\hline & & & 0.56 & 0 & 0.56 & 0.33 & 0.58 & 0.49 & \\
\hline $\begin{array}{r}93.4 \\
0.063\end{array}$ & & $\begin{array}{l}\text { ND } \\
0.60\end{array}$ & $\begin{array}{l}\text { ND } \\
0.56\end{array}$ & $\begin{array}{l}\text { ND } \\
0.51\end{array}$ & $\begin{array}{l}\text { ND } \\
0.53\end{array}$ & & & $\begin{array}{l}\text { ND } \\
0.47\end{array}$ & $\begin{array}{l}\text { ND } \\
0.26\end{array}$ \\
\hline $\begin{array}{r}91.7 \\
0.088\end{array}$ & $\begin{array}{r}90 \cdot 3 \\
0 \cdot 103\end{array}$ & & $\begin{array}{l}\text { ND } \\
0.60\end{array}$ & $\begin{array}{l}\text { ND } \\
0.55\end{array}$ & $\begin{array}{l}\text { ND } \\
0.55\end{array}$ & & & & $\begin{array}{l}\text { ND } \\
0 \cdot 28\end{array}$ \\
\hline $\begin{array}{r}88 \cdot 6 \\
0 \cdot 124\end{array}$ & $\begin{array}{r}88.9 \\
0.121\end{array}$ & $\begin{array}{r}90 \cdot 1 \\
0 \cdot 106\end{array}$ & & $\begin{array}{l}\text { ND } \\
0.60\end{array}$ & $\begin{array}{l}\text { ND } \\
0 \cdot 60\end{array}$ & $\begin{array}{l}\text { ND } \\
0.58\end{array}$ & & & $\begin{array}{l}\text { ND } \\
0.25\end{array}$ \\
\hline $\begin{array}{r}88 \cdot 2 \\
0 \cdot 128\end{array}$ & $\begin{array}{r}87.0 \\
0.143\end{array}$ & $\begin{array}{r}88.4 \\
0.125\end{array}$ & $\begin{array}{r}90 \cdot 0 \\
0 \cdot 108\end{array}$ & & $\begin{array}{l}0.62 \\
0.57\end{array}$ & & & & \\
\hline $\begin{array}{r}88.6 \\
0 \cdot 124\end{array}$ & $\begin{array}{r}87.7 \\
0.134\end{array}$ & $\begin{array}{r}88 \cdot 4 \\
0 \cdot 126\end{array}$ & $\begin{array}{r}90 \cdot 6 \\
0 \cdot 100\end{array}$ & $\begin{array}{r}89 \cdot 1 \\
0 \cdot 118\end{array}$ & & $\begin{array}{l}0.70 \\
0.60\end{array}$ & & & \\
\hline $\begin{array}{r}87 \cdot 7 \\
0 \cdot 134\end{array}$ & $\begin{array}{r}88.4 \\
0.125\end{array}$ & $\begin{array}{r}87.7 \\
0 \cdot 134\end{array}$ & $\begin{array}{r}89.4 \\
0.115\end{array}$ & $\begin{array}{r}88.4 \\
0 \cdot 126\end{array}$ & $\begin{array}{r}90 \cdot 1 \\
0 \cdot 106\end{array}$ & & $\begin{array}{l}0.69 \\
0.72\end{array}$ & & $\begin{array}{l}0.33 \\
0.25\end{array}$ \\
\hline $\begin{array}{r}89 \cdot 6 \\
0 \cdot 112\end{array}$ & $\begin{array}{r}89.5 \\
0.114\end{array}$ & $\begin{array}{r}89.3 \\
0 \cdot 115\end{array}$ & $\begin{array}{r}91.2 \\
0.094\end{array}$ & $\begin{array}{r}90.2 \\
0.105\end{array}$ & $\begin{array}{r}92 \cdot 2 \\
0.082\end{array}$ & $\begin{array}{r}93.4 \\
0.068\end{array}$ & & $\begin{array}{l}0.56 \\
0.58\end{array}$ & $\begin{array}{l}0 \cdot 31 \\
0 \cdot 28\end{array}$ \\
\hline $\begin{array}{r}86 \cdot 4 \\
0 \cdot 150\end{array}$ & $\begin{array}{r}85.8 \\
0.157\end{array}$ & $\begin{array}{r}86 \cdot 1 \\
0 \cdot 154\end{array}$ & $\begin{array}{r}86.7 \\
0 \cdot 147\end{array}$ & $\begin{array}{r}86 \cdot 4 \\
0 \cdot 150\end{array}$ & $\begin{array}{r}87.8 \\
0.132\end{array}$ & $\begin{array}{r}86.6 \\
0 \cdot 148\end{array}$ & $\begin{array}{r}89 \cdot 4 \\
0 \cdot 114\end{array}$ & & $\begin{array}{l}0.31 \\
0.25\end{array}$ \\
\hline $\begin{array}{r}76.4 \\
0.283\end{array}$ & $\begin{array}{r}76.7 \\
0.280\end{array}$ & $\begin{array}{r}77.8 \\
0.264\end{array}$ & $\begin{array}{r}75.9 \\
0.291\end{array}$ & $\begin{array}{r}76.7 \\
0 \cdot 280\end{array}$ & $\begin{array}{r}76.5 \\
0.282\end{array}$ & $\begin{array}{r}75.9 \\
0.290\end{array}$ & $\begin{array}{r}77 \cdot 8 \\
0 \cdot 264\end{array}$ & $\begin{array}{r}76.1 \\
0.288\end{array}$ & \\
\hline
\end{tabular}

the major actinomycete groupings as defined by $S_{\mathrm{AB}}$ (binary association coefficient; Fox et al., 1977 ) values. The fact that the sequences generated by reverse transcriptase are seldom complete means that RNAase T1 resistant catalogues, upon which the published dendrograms are based, cannot be extracted. Woese (1987) has published a calibration plot which expresses the correlation between homology values obtained for full $16 \mathrm{~S}$ rRNA sequences and $S_{\mathrm{AB}}$ values. 


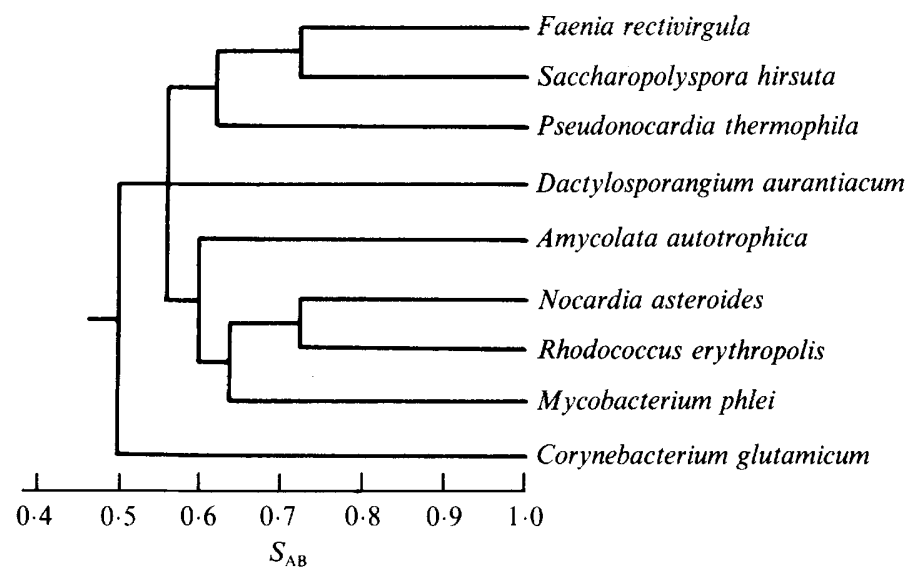

Fig. 3. Dendrogram showing the relationships between the test and reference strains, based upon the derived $S_{\mathrm{AB}}$ values shown in Table 1, upper right section.

Table 1 contains $S_{\mathrm{AB}}$ values which were derived from this calibration plot and our partial $(73 \%$ of the length of the $E$. coli sequence) sequence data. $S_{\mathrm{AB}}$ values produced from cataloguing data for the same strain are included where available and, as possibly expected, there is incomplete agreement between the values (Table 1). In most cases, the derived values are lower by up to $0 \cdot 1 S$ than the $S_{\mathrm{AB}}$ values obtained by experiment. Better congruence might be obtained if the calibration curve were based upon more data and included more actinomycete sequences. A dendrogram constructed from the derived $S_{\mathrm{AB}}$ values using average linkage clustering is presented in Fig. 3. It is encouraging that, despite the discrepancies mentioned above, the branching order (but not necessarily the branch length) obtained for the reference organisms, i.e. members of Dactylosporangium, Nocardia, Rhodococcus, Mycobacterium and Corynebacterium, is the same as that obtained using published $S_{\mathrm{AB}}$ values (Stackebrandt \& Woese, 1981 : Stackebrandt, 1986). This confirms that Faenia rectivirgula, Pseudonocardia thermophila and Saccharopolyspora hirsuta form a distinct subline within the broader grouping which comprises Mycobacterium, Dactylosporangium and their relatives (Stackebrandt, 1986).

An advantage of using reverse transcriptase is that it provides sequences from the variable regions of the 16S RNA molecule. These domains may show considerable sequence diversity between closely related species (Woese, 1987) and can therefore be used as target sites for taxonspecific probes which can be used for rapid identification, as already demonstrated for Mycoplasma species (Göbel et al., 1987). The biotechnological importance of certain members of the wall type IV actinomycetes as producers of antibiotics suggests that the development of probes for use in industrial screening programs is desirable. From our data we suggest that the most appropriate target sites for probe hybridization are those indicated in Fig. 1.

This work was supported in part by a Society for General Microbiology Research Fund Grant to T.M. E. and a grant to E.S. from the Gesellschaft für Biotechnologische Forschung for performing research of relevance to the German Collection of Microorganisms.

\section{REFERENCES}

Brosius, J., Palmer, J. L., Kennedy, J. P. \& Noller, H. F. (1978). Complete nucleotide sequence of a $16 \mathrm{~S}$ ribosomal RNA gene from Escherichia coli. Proceedings of the National Academy of Sciences of the United States of America 75, 4801-4805.

Chen, E. G. \& Seeburg, P. H. (1985). Supercoil sequencing: a fast and simple method for sequencing plasmid DNA. DNA 4, 165-170.
Collins, M. D., Pirouz, T., Goodfellow, M. \& MINNIKIN, D. E. (1977). Distribution of menaquinones in actinomycetes and corynebacteria. Journal of General Microbiology 100, 221-230.

Collins, M. D., Goodfellow, M. \& Minnikin, D. E. (1982). Fatty acid composition of some mycolic acid containing coryneform bacteria. Journal of General Microbiology 128, 2503-2509. 
De Borde, D. C., Naeve, C. W., Herlocher, M. L. \& MAASSAB, H. F. (1986). Resolution of a common RNA sequencing ambiguity by terminal deoxynucleotidyl transferase. Analytical Biochemistry 157, 275-282.

Dorokhova, L. A., Agre, N. S., KalakoutskiI, L. V. \& Krassilnikov, N. A. (1969). Fine structure of sporulating hyphae and spores in a thermophilic actinomycete Micropolyspora rectivirgula. Journal de microscopie 8, 845-854.

EMBley, T. M., GoOdFEllow, M., O’DonNell, A. G., Rose, D. \& Minnikin, D. E. (1986). Chemical criteria in the classification of some mycolateless wall chemotype IV actimomycetes. In Biological Biochemical and Biomedical Aspects of Actinomycetes, pp. 553-556. Edited by G. Szabo, S. Biro \& M. Goodfellow. Budapest: Akademiai Kiado.

EMBley, T. M., WAIT, R., DOBSON, G. \& GoOdFEllow, M. (1987). Fatty acid composition in the classification of Saccharopolyspora hirsuta. FEMS Microbiology Letters 41, 131-135.

Embley, T. M., Rostron, J., O'Donnell, A. G. \& Goodfellow, M. (1988). Chemotaxonomy of wall type IV actinomycetes which lack mycolic acids. Journal of General Microbiology 134, 953-959.

Felsenstein, J. (1982). Numerical methods for inferring evolutionary trees. Quarterly Review of Biology 57, 379-404.

Fitch, W. M. \& Margoliash, E. (1967). Construction of phylogenetic trees: a method based on mutation distances as estimated from cytochrome $c$ sequences is of general applicability. Science 155, 279-284.

Fox, G. E., Pechman, K. J. \& Woese, C. R. (1977). Comparative cataloging of $16 \mathrm{~S}$ ribosomal ribonucleic acid: molecular approach to prokaryotic systematics. International Journal of Systematic Bacteriology 27, 44-57.

Göbel, U. B., Geiser, A. \& Stanbridge, E. J. (1987). Oligonucleotide probes complementary to variable regions of ribosomal RNA discriminate between Mycoplasma species. Journal of General Microbiology 133, 1969-1974.

Goodfellow, M. \& Cross, T. (1984). Classification. In The Biology of the Actinomycetes pp. 7-146. Edited by M. Goodfellow, M. Mordarski \& S. T. Williams, London: Academic Press.

Goodfellow, M. \& Pirouz, T. (1982). Numerical classification of sporoactinomycetes containing meso-diaminopimelic acid in the cell wall. Journal of General Microbiology 128, 503-507.

Green, C. J., Steward, G. C., Hollis, M. A., Vold, B. S. \& BoTT, K. F. (1985). Nucleotide sequence of Bacillus subtilis ribosomal RNA operon, rrnB. Gene 37, 261-266.

HENSSEN, A. \& SCHÄFER, D. (1971). Emended description of the genus Pseudonocardia Henssen and description of a new species of Pseudonocardia spinosa Schäfer. International Journal of Systematic Bacteriology 21, 29-34.

HORI, H. (1975). Evolution of 5S RNA. Journal of Molecular Evolution 7, 75-88.

JoHnson, J. L. (1981). Genetic characterization. In Manual of Methods for General Bacteriology, pp. 450 475. Edited by P. Gerhard, R. G. E. Murray, R. N.
Costilow, E. W. Nester, W. A. Wood, N. R. Krieg \& G. Briggs-Phillips. Washington, DC: American Society for Microbiology.

LACEY, J. \& GOODFEllow, M. (1975). A novel actinomycete from sugar cane bagasse: Saccharopolyspora hirsuta gen. et sp. nov. Journal of General Microbiology 88, 75-85.

KIRBY, K. S. (1968). Isolation of nucleic acids with phenolic solvents. Methods in Enzymology 12, 87-99.

KROPPENSTEDT, R. M. (1985). Fatty acids and menaquinone analysis of actinomycetes and related organisms. In Chemical Methods in Bacterial Systematics, pp. 173-189. Edited by M. Goodfellow \& D. E. Minnikin. London: Academic Press.

Lane, D. J., Pace, B., Olsen, G. J., Stahl, D. A., SogIn, M. L. \& PACE, N. R. (1985). Rapid determination of $16 \mathrm{~S}$ ribosomal RNA sequences for phylogenetic analyses. Proceedings of the National Academy of Sciences of the United States of America 82, 6955-6959.

LeChevalier, M. P. \& Lechevalier, H. A. (1970). Chemical composition as a criterion in the classification of aerobic actinomycetes. International Journal of Systematic Bacteriology 20, 435-443.

Lechevalier, M. P., Debievre, C. \& Lechevalier, H. A. (1977). Chemotaxonomy of aerobic actinomycetes: phospholipid composition. Biochemical Systematics and Ecology 5, 249-260.

Lechevalier, M. P., Prauser, H., Labeda, D. P. \& RUAN, J.-S. (1986). Two new genera of nocardioform actinomycetes: Amycolata gen. nov. and Amycolatopsis gen. nov. International Journal of Systematic Bacteriology 36, 29-37.

MinNikin, D. E. \& Goodfellow, M. (1981). Lipids in the classification of actinomycetes. Zentralblatt für Bakteriologie, Parasitenkunde, Infektionskrankheiten und Hygiene, Supplement 11, 99-109.

QU, L. H., Michot, B. \& Bachellerie, G.-P. (1983). Improved methods for structure probing in large RNAs: a rapid heterologous sequencing approach is coupled to the direct mapping of nuclease accessible sites. Application to the $5^{\prime}$ terminal domain of eukaryotic 28S rRNA. Nucleic Acids Research 11, 5903-5920.

QueEN, C. \& KoRN, L. J. (1984). A comprehensive sequence analysis program for the IBM personal computer. Nucleic Acids Research 12, 581-599.

STACKEBRANDT, E. (1986). The significance of wall types in phylogenetically based taxonomic studies on actinomycetes. In Biological, Biochemical and Biomedical Aspects of Actinomycetes, pp. 497-506. Edited by G. Szabo, S. Biro \& M. Goodfellow. Budapest: Akademiai Kiado.

StaCKebrandT, E. \& SchleIfER, K.-H. (1984). Molecular systematics of actinomycetes and related organisms. In Biological, Biochemical and Biomedical Aspects of Actinomycetes, pp. 485-504. Edited by L. Ortiz-Ortiz, L. F. Bojalil \& V. Yakoleff. Orlando: Academic Press.

StackebrandT, E. \& Woese, C. R. (1981). Towards a phylogeny of the actinomycetes and related organisms. Current Microbiology 5, 197-202.

WOESE, C. R. (1987). Bacterial evolution. Microbiological Reviews 51, 221-271. 